\title{
URGENSI BERZAKAT MELALUI AMIL DALAM PANDANGAN ILMU EKONOMI ISLAM
}

\author{
Widi Nopiardo \\ Fakultas Ekonomi dan Bisnis Islam IAIN Batusangkar \\ J1. Jenderal Sudirman No. 137, Lima Kaum Batusangkar \\ e-mail: widinopiardo@rocketmail.com
}

\begin{abstract}
Zakat (Divine Tax) is the only worship in Islam where the person responsible for collecting the Zakat mentioned in the Quran. This person is called amil (collector). Therefore, the legal basis for the amil is obviously stated in the Quran and the Sunnah. Even, the prophet pbuh and the companions have shown how to pay zakat through the amil. There must be no doubts paying zakat through amil. However, some phenomena show that the rakat that is paid directly by the tax payer (muzaki) to those who deserve to have it (mustabik). Those phenomena leave a very serious question: whether the receivers are truly mustabik. This is quite reasonable since most of the muzaki distribute their own zakat to their own relatives while many others in their neighborhood deserve to receive more than the others due to their economic conditions.
\end{abstract}

Kata kunci: urgensi, zakat, amil

\section{PENDAHULUAN}

$\tau$ idak bisa dipungkiri bahwa selama ini pemahaman yang berkembang di tengah masyarakat adalah bahwa ibadah zakat itu lebih utama dan lebih baik apabila muzaki atau wajib zakat, menyalurkan langsung zakatnya kepada para mustahik, tanpa melalui perantara amil. Dengan pemahaman seperti ini, maka praktek mendistribusikan zakat berupa uang kepada para mustahik yang mengantri, masih dapat kita saksikan.

Kendati menyalurkan zakat langsung ke mustahik tidak dilarang, namun misi zakat untuk mengentaskan kemiskinan dipastikan akan sulit terwujud. Juga dari sisi kemanusiaan, praktek tersebut kurang manusiawi dan cenderung merendahkan harkat dan martabat mustahik. Dengan pola seperti ini, maka dampak dari penyaluran zakat hanya akan bersifat jangka sangat pendek, harapan untuk mewujudkan mustahik menjadi muzaki akan sulit tercapai. Adapun tujuan jangka panjang yang ingin dicapai di mana tidak terlepas dari kajian ilmu ekonomi Islam, yaitu memenuhi kebutuhan hidup dan meningkatkan daya tahan perekonomian mustahik, bahkan mentransformasi mereka dari mustahik menjadi muzaki.

Pentingnya berzakat melalui amil dalam hal ini seperti BAZNAS dan LAZ agaknya sejalan dengan visi zakat untuk kesejahteraan umat, di mana zakat merupakan instrumen keuangan dalam ilmu ekonomi Islam.

Untuk mengkaji urgensi berzakat melalui amil dalam pandangan ilmu ekonomi Islam akan dijelaskan tentang konsep zakat, konsep amil, dan urgensi berzakat melalui amil dalam pandangan ilmu ekonomi Islam. 


\section{METODE PENELITIAN}

Jenis penelitian ini adalah penelitian normatif menggunakan analisis kualitatif yakni dengan menjelaskan data-data yang ada dengan kata-kata atau pernyataan bukan dengan angka-angka. Dan menggunakan pendekatan konsep (conceptual approach) tentang urgensi berzakat melalui amil melalui penelitian perpustakaan ataupun studi dokumen disebabkan penelitian ini lebih banyak dilakukan terhadap data yang bersifat sekunder

Adapun jenis data dalam penelitian ini adalah data sekunder, yaitu data dari buku-buku, media internet, dokumen BAZNAS, dan penelitian terdahulu yang mengkaji tentang zakat melalui amil.

Sedangkan teknik pengumpulan data, yaitu dengan menelaah buku-buku, media internet, dokumen BAZNAS, dan penelitian terdahulu.

Teknik analisis data, yaitu dengan menggunakan data kualitatif dengan metode analisis dan kajian normatif berdasarkan sumber-sumber tertulis yang ada.

\section{PEMBAHASAN}

\section{Konsep Zakat}

\section{Definisi Zakat}

Secara etimologis, zakat berasal dari kata dasar bahasa Arab zaka yang berarti berkah, tumbuh, bersih, baik, dan bertambah. Sedangkan secara terminologis di dalam fikih, zakat adalah sebutan atau nama bagi sejumlah harta tertentu yang diwajibkan Allah Swt supaya diserahkan kepada orang-orang yang berhak (mustahiq) oleh orang-orang yang wajib mengeluarkan zakat (muzaki) (Ambary, dkk., 1999: 224).
Ada pendapat beberapa ulama mengenai pengertian zakat, yaitu (Wahbah Al Zuhayly, 1995: 83-84):

1. Menurut mazhab Maliki, definisi zakat adalah "mengeluarkan sebagian yang khusus dari harta yang khusus pula yang telah mencapai nisab (batas kuantitas yang mewajibkan zakat) kepada orangorang yang berhak menerimanya (mustahiq)nya. Dengan catatan, kepemilikan itu penuh dan mencapai haul (setahun), bukan barang tambang dan bukan pertanian."

2. Menurut mazhab Hanafi, zakat adalah "menjadikan sebagian harta yang khusus dari harta yang khusus sebagai milik orang yang khusus, yang ditentukan oleh syari'at karena Allah Swt."

3. Menurut mazhab Syafi'i, zakat adalah sebuah ungkapan untuk keluarnya harta atau tubuh sesuai dengan cara khusus.

4. Menurut mazhab Hambali, zakat adalah hak yang wajib (dikeluarkan) dari harta yang khusus untuk kelompok yang khusus pula.

Menurut istilah ekonomi, zakat merupakan tindakan pemindahan kekayaan dari golongan kaya kepada golongan tidak punya (Adiwarman Karim, 2001: 32). Salah satu ajaran penting yang terdapat dalam agama Islam adalah urgensi zakat kaitannya dengan pengentasan kemiskinan. Sebagai sebuah dinamika keagamaan, zakat merupakan bentuk kesaksian manusia (syahadah al-insan) pada rukun Islam yang keempat di hadapan Allah yang muaranya tertuju pada dimensi kemanusiaan.

\section{Landasan Kewajiban Zakat}

Zakat telah diwajibkan di Madinah pada bulan Syawal tahun kedua hijrah 
setelah kepada umat Islam diwajibkan berpuasa Ramadhan.

Zakat merupakan salah satu rukun Islam yang selalu disejajarkan dengan shalat. Inilah yang menunjukkan betapa pentingnya zakat sebagai salah satu rukun Islam (Abdul Hamid Mahmud, 2006: 1). Dasar-dasar atau landasan kewajiban mengeluarkan zakat disebutkan dalam:

\section{Landasan dalam Alquran}

1. Surat al-Baqarah: 43

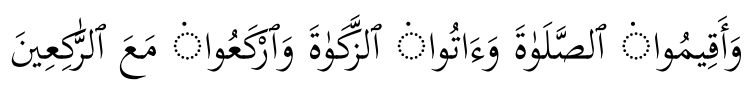

Dan dirikanlah shalat, tunaikanlah zakat dan ruku'lah beserta orang-orang yang ruku' (Q.S. al-Baqarah [2]: 43).

2. Surat at-Taubah: 103

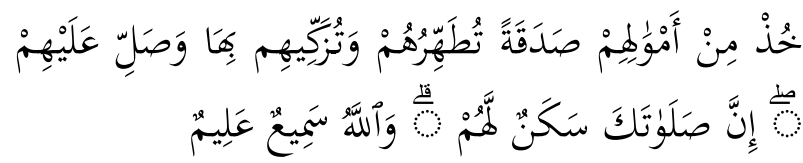

Ambillah zakat dari sebagian harta mereka, dengan zakat itu kamu membersihkan dan mensucikan mereka dan mendoalah untuk mereka. Sesungguhnya doa kamu itu (menjadi) ketenteraman jiwa bagi mereka. dan Allah Maha mendengar lagi Maha Mengetahui (Q.S. at-Taubah [9]: 103).

3. Surat al-An'am: 141

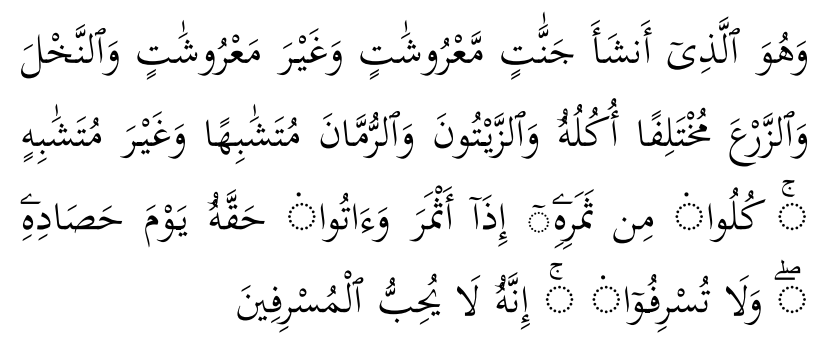

Dan Dialah yang menjadikan kebun-kebun yang berjunjung dan yang tidak berjunjung, pohon korma, tanam-tanaman yang bermacam-macam buahnya, zaitun dan delima yang serupa (bentuk dan warnanya) dan tidak sama (rasanya).
Makanlah dari buahnya (yang bermacammacam itu) bila dia berbuah, dan tunaikanlah haknya di hari memetik hasilnya (dengan disedekahkan kepada fakir miskin); dan janganlah kamu berlebihlebihan. Sesungouhnya Allah tidak menyukai orang yang berlebih-lebihan (Q.S. al-An'am [6]: 141).

4. Surat at-Taubah: 5

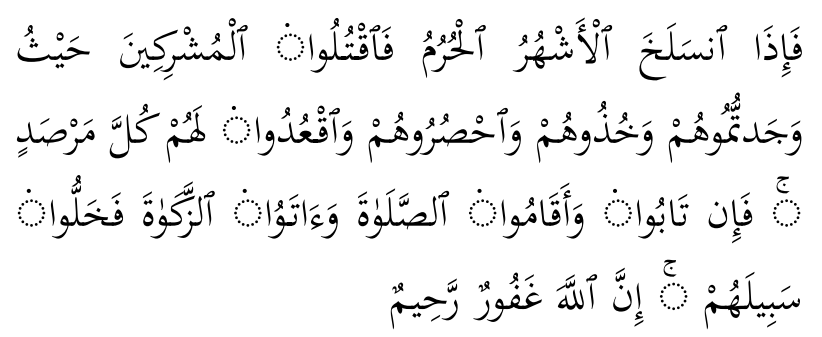

Apabila sudah habis bulan-bulan haram itu maka bunuhlah orang-orang musyrikin itu di mana saja kamu jumpai mereka, dan tangkaplah mereka. Kepunglah mereka dan intailah di tempat pengintaian. Jika mereka bertaubat dan mendirikan shalat dan menunaikan zakat, maka berilah kebebasan kepada mereka untuk berjalan. Sesungguhnya Allah Maha Pengampun lagi Maha Penyayang (Q.S. at-Taubah [9]: 5) (Al-Fauzan, 2006: 244).

\section{Landasan dalam Sunnah}

1. Hadis yang diriwayatkan oleh Bukhari dan Muslim dari Abdullah bin Umar Rasulullah bersabda:

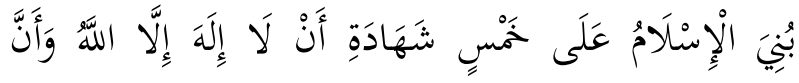

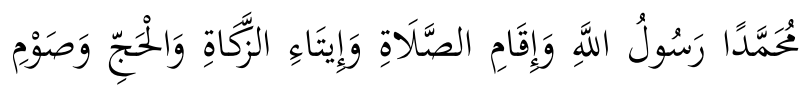

$$
\begin{aligned}
& \text { رَمَضَانَ }
\end{aligned}
$$

Islam dibangun di atas lima (landasan); persaksian tidak ada Ilah selain Allah dan sesungguhnya Muhammad utusan Allah, mendirikan shalat, menunaikan zakat, haji dan puasa Ramadhan (H.R. Bukhari Nomor 7) 
88 Jurnal Ilmiah Sygari'ah, Volume li, Nomor l, Jantuari-Juni 2006

2. Hadis yang diriwayatkan oleh Ahmad dan Muslim dari Syaiban bin Farrukh

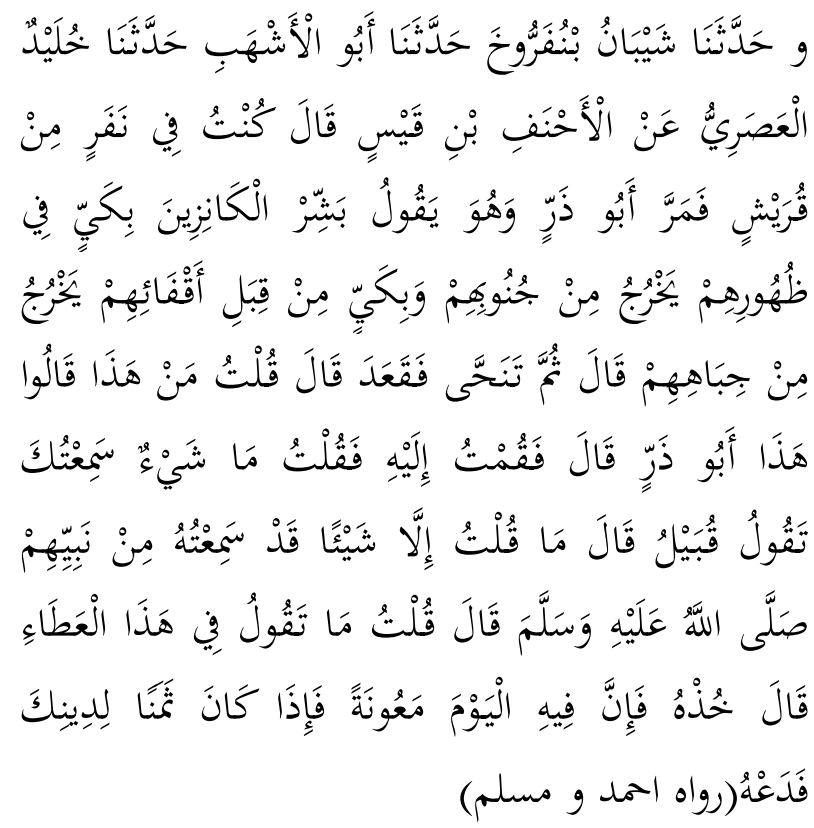

Dan Telah menceritakan kepada kami [Syaiban bin Farrukh] telah menceritakan kepada kami [Abul Asyhab] telah menceritakan kepada kami [Khulaid Al 'Ashari] dari [Al Ahnaf bin Qais] ia berkata; Saya pernah berada dalam sebuah rombongan orang-orang Quraisy, lalu [Abu Dzar] lewat sambil mengatakan, "Berilah kabar gembira kepada orang-orang yang menumpuk harta (dan tidak membayar zakatnya), bahwa mereka akan disiksa dengan seterika di punggung mereka yang keluar dari lambung dari tengkuk mereka." Setelah itu, ia menyingkir dan duduk. Kemudian saya bertanya, "Siapa ini?" orang-orang pun menjawab, "Ini adalah Abu Dzar." Maka aku pun mendekatinya dan bertanya, "Apa ucapanmu yang baru saja aku dengar tadi?" Abu Dzar menjawab, "Tidaklah aku mengatakan sesuatu tadi, kecuali aku telah mendengarnya dari Nabi shallallahu 'alaihi wasallam." Kemudian aku tanyakan, "Bagaimana pendapatmu tentang pemberian ini?" Abu Dzar menjawab, "Ambillah karena pemberian itu sekarang sebagai pertolongan, namun jika pemberian itu untuk membayar agamamu, maka tinggalkanlah. (H.R. Ahmad Nomor 20511 dan Muslim Nomor 1657)

3. Hadis yang diriwayatkan oleh Thabrani dalam buku Al Ausath dan As Saghir dari Ali

$$
\begin{aligned}
& \text { ان الله فرض على اغنياء المسا عين في اموا لهم بقد ر } \\
& \text { الذي يسع فقرا ئهم ولن يجهد الفقراء اذا جا عوا او عروا } \\
& \text { الا بما يصنع اغنيا ئهم الا وان الله يحا سبهم حسابا } \\
& \text { شديدا و يعذ بهم عذاباليما }
\end{aligned}
$$

Allah Ta'ala mewajibkan zakat pada harta orang-orang kaya dari kaum muslimin sejumlah yang dapat melapangi orangorang miskin di antara mereka. Fakir miskin itu tiadalah akan menderita menghadapi kelaparan dan kesulitan sandang kecuali karena perbuatan golongan kaya, ingatlah Allah akan mengadili mereka nanti secara tegas dan menyiksa mereka dengan pedih (H.R. Thabrani) (Sabiq, 1982: 193).

\section{Konsep Amil}

\section{Pengertian Amil}

Beberapa pengertian amil sebagai berikut:

1. Menurut Imam Syafi'i amilun adalah orang-orang yang diangkat untuk memungut zakat dari pemilikpemiliknya (Asnaini, 2008: 54.). Dari pengertian tersebut maka amil ialah orang-orang yang bertugas mengumpulkan zakat.

2. Menurut Yusuf Qardhawi 'amilun adalah semua orang yang bekerja dalam perlengkapan administrasi urusan zakat, baik urusan pengumpulan, penyimpanan, pencatatan, perhitungan maupun yang mencatat keluar masuk zakat dan 
membagi pada para mustahiknya (Yusuf Qardhawi, terj., Salman Harun, Didin Hafidhuddin dan Hasanuddin, 2002: 545).

3. Mengenai petugas pemungutan zakat, Hasbi memilih pendapat Abu Hanifah dan Malik yang menyatakan bahwa amilin adalah petugas yang diberi upah yang diambil dari harta pungutan zakat itu menurut kadar jerih payah mereka (Nouruzzaman Shiddiqi, t.th.: 209).

4. Amil zakat ialah semua pihak yang bertindak mengerjakan yang berkaitan dengan pengumpulan, penyimpanan, penjagaan, pencatatan, dan penyaluran atau distribusi harta zakat. (Hikmat Kurnia dan A. Hidayat, 2008: 142)

Jadi, amil zakat adalah orang-orang yang terlibat atau ikut aktif dalam kegiatan pelaksanaan zakat yang dimulai dari sejak mengumpulkan zakat dari muzaki sampai mendistribusikannya kepada mustahik.

\section{Dasar Hukum Amil dalam Alquran dan Sunnah}

Kedudukan amil sendiri juga sudah dilegalkan agama, dan bahkan merupakan kewajiban bagi pemerintah. Dan ia sendiri sudah punya landasan hukum yang jelas, beberapa di antaranya:

\section{Dasar Hukum Amil dalam Alquran}

1. Q.S. at-Taubah [9]: 130

Amil zakat sebagai pengelola, tapi berhak menerima zakat, dapat disimpulkan bahwa sejak pertama kali zakat diwajibkan, Alquran telah mengisyaratkan yang terdapat dalam surat at-Taubah ayat 103 tentang keharusan adanya pengelola zakat yang berwenang untuk menentukan kebijaksanaan-kebijaksanaan yang berkaitan dengan pelaksanaan zakat (Ahmad Azhar Basyir, 1997: 76.).

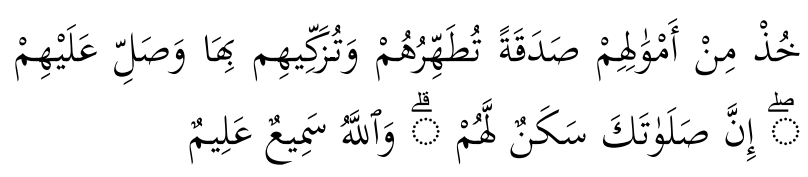

Ambillah zakat dari sebagian harta mereka, dengan zakat itu kamu membersihkan dan mensucikan mereka dan mendoalah untuk mereka. Sesungguhnya doa kamu itu (menjadi) ketenteraman jiwa bagi mereka. dan Allah Maha mendengar lagi Maha Mengetahui (Q.S. at-Taubah [9]: 103).

2. Q.S. at-Taubah [9]: 60

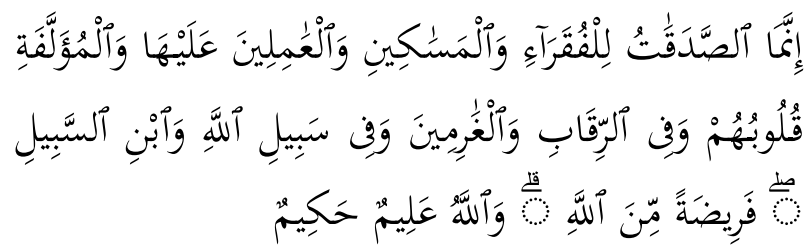

Sesungguhnya sedekah-sedekah (zakat) itu hanyalah untuk orang-orang fakir, dan orang-orang miskin, dan amil-amil yang mengurusnya, dan orang-orang muallaf yang dijinakkan hatinya, dan untuk hamba-hamba yang hendak memerdekakan dirinya, dan orang-orang yang berhutang, dan untuk (dibelanjakan pada) jalan Allah, dan orang-orang musafir (yang keputusan) dalam perjalanan. (Ketetapan hukum yang demikian itu ialah) sebagai satu ketetapan (yang datangnya) dari Allah. Dan (ingatlah) Allah Maha Mengetahui, lagi Maha Bijaksana. (Q.S. at-Taubah [9]: 60)

M. Quraish Shihab dalam Tafsir AlMishbah menerangkan bahwa amil zakat adalah pengelola-pengelolanya yakni yang mengumpulkan zakat, mencari, dan menetapkan siapa yang wajar menerima lalu membagikannya. Jadi yang jelas amil zakat adalah yang melakukan pengelolaan terhadap zakat, baik mengumpulkan, 
menentukan siapa yang berhak, mencari mereka yang berhak, maupun membagi dan mengantarkannya kepada mereka (M. Quraish Shihab, 2002: 629).

Lebih lanjut M. Quraish Shihab menguraikan bahwa kata عليها ('alaiha) dalam kalimat والعامليناعليها (wal 'amilina alaiha) memberi kesan bahwa para pengelola itu melakukan kegiatan mereka dengan sungguh-sungguh dan mengakibatkan keletihan. Ini karena kata على ('ala) mengandung makna penguasaan dan kemantapan atas sesuatu. Penggunaan rangkaian kedua kata itu untuk menunjuk para pengelola, memberi kesan bahwa mereka berhak memperoleh bagian dari zakat karena dua hal. Pertama, karena upaya mereka yang berat, dan kedua karena upaya tersebut mencakup kepentingan sedekah (M. Quraish Shihab, 2002: 629).

Allah berfirman: al-amiluna 'alaiha (pengurus-pengurus zakat), Allah tidak berfirman al-amiluna fiha (penguruspengurus dalam hal zakat). Firman ini mengisyaratkan bahwa mereka memiliki semacam kewenangan untuk memungut zakat dari orang-orang yang berhak mengeluarkan zakat sekaligus mendistribusikan kepada orang yang berhak menerimanya (Muhammad bin shalih al-Utsaimin, 2011: 298-299).

\section{Dasar Hukum Amil dalam Sunnah}

1. Hadis yang diriwayatkan oleh Bukhari dan Muslim dari Ibnu Abbas

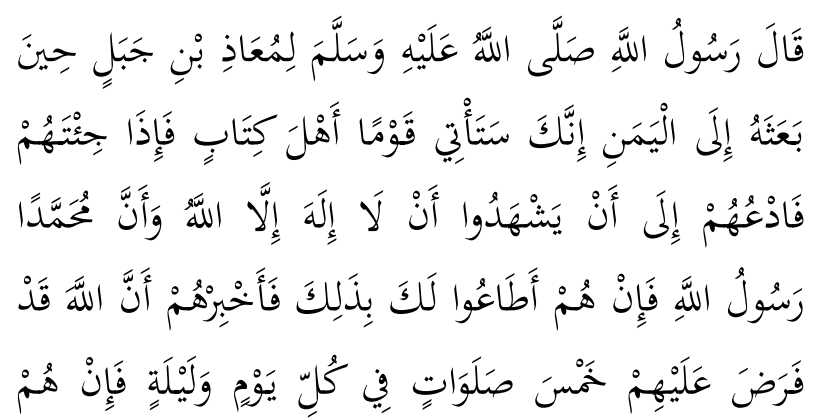

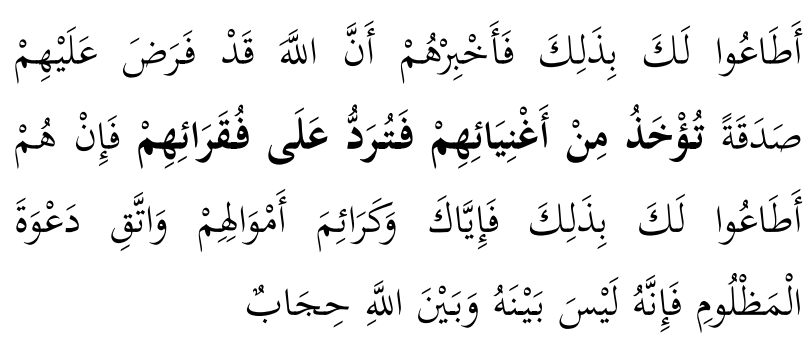

Rasulullah Shallallahu'alaihiwasallam berkata, kepada Mu'adz bin Jabal Radhiyalahu'anhu ketika Beliau mengutusnya ke negeri Yaman: "Sesungguhnya kamu akan mendatangi kaum Ahlul Kitab, jika kamu sudah mendatangi mereka maka ajaklah mereka untuk bersaksi tidak ada Ilah yang berhak disembah kecuali Allah dan bahwa Muhammad adalah utusan Allah. Jika mereka telah mentaati kamu tentang hal itu, maka beritahukanlah mereka bahwa Allah mewajibkan bagi mereka shalat lima waktu pada setiap hari dan malamnya. Jika mereka telah mentaati kamu tentang hal itu maka beritahukanlah mereka bahwa Allah mewajibkan bagi mereka zakat yang diambil dari kalangan orang mampu dari mereka dan dibagikan kepada kalangan yang faqir dari mereka. Jika mereka mentaati kamu dalam hal itu maka janganlah kamu mengambil harta-harta terhormat mereka dan takutlah terhadap doanya orang yang terzalimi karena antara dia dan Allah tidak ada hijab (pembatas yang menghalangi) nya". (HR Bukhari dari Ibnu Abbas) dan Muslim juga meriwayatkan dari Ibnu Abbas

Hadis di atas merupakan perintah Nabi Muhammad Saw kepada Mu'adz bin Jabal waktu diutus ke Yaman untuk mengambil zakat dari orang-orang kaya dan akan dibagikan kepada orang-orang fakir di antara mereka (Masjfuk Zuhdi, 1997: 258.) Yang dijadikan dalil dari hadits tersebut adalah kalimat " $t u$ 'khodzu min aghniyaa ihim" dan "fa turaddu 'ala fuqara ihim". Walaupun bentuk kalimatnya 
merupakan kalam khabar (kalimat berita biasa), dan juga mabni majhul, tapi maknanya sangat jelas menandaskan bahwa zakat itu harus dipungut oleh pemimpin. Dan kemudian harus dibagikan kepada orang-orang yang fakir di antara mereka (Abdul Bari Shoim, 1978: 82)

2. Hadis yang diriwayatkan oleh Bukhari dan Muslim dari Abi Humaid AlSaa'idy

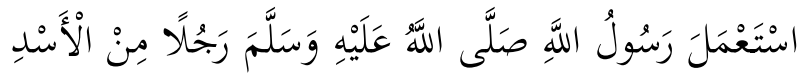

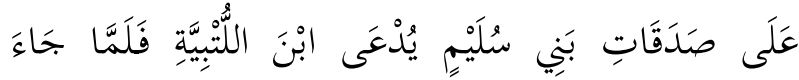

$$
\begin{aligned}
& \text { حَاسَبَهُ }
\end{aligned}
$$

Rasulullah shallallahu 'alaihi wasallam memperkerjakan seorang laki-laki untuk mengurus zakat Bani Sulaim yang dikenal dengan sebutan Ibnu Al Latbiyah. Ketika orang itu kembali, Beliau memberinya (upah dari bagian zakat) (HR Bukhari dari Abi Humaid Al-Saa'idy) Muslim juga meriwayatkan dari Abi Humaid Al-Saa'idy.

3. Hadis yang diriwayatkan oleh Muslim dari seorang Tabi'in yang bernama Ibnu Al-Sa'di

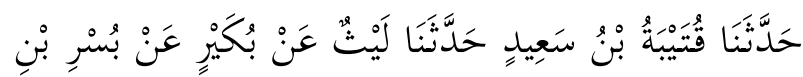

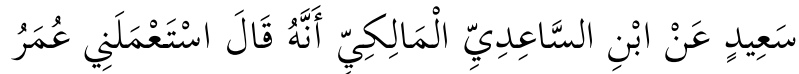

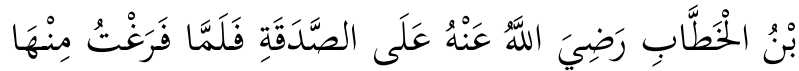

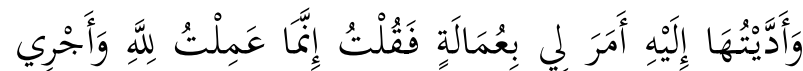

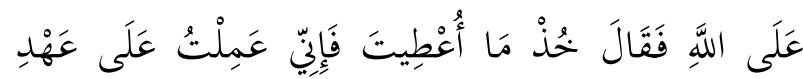

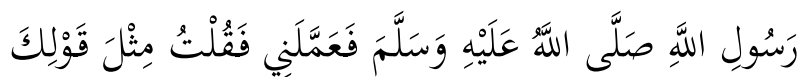

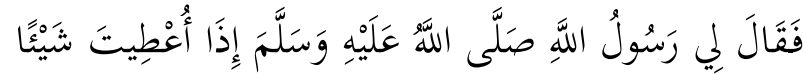

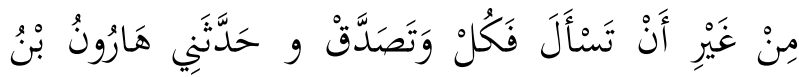

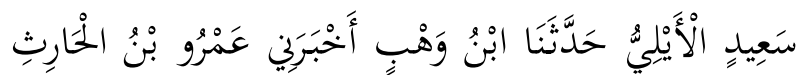

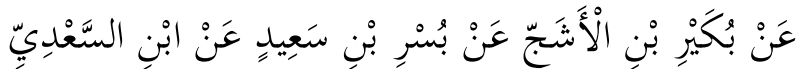

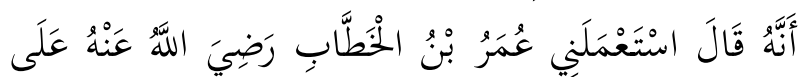

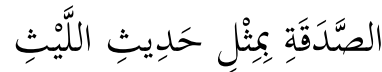

Telah menceritakan kepada kami [Qutaibah bin Sa'id] telah menceritakan kepada kami [Laits] dari [Bukair] dari [Busr bin Sa'id] dari [Ibnu As Sa'idi Al Maliki] bahwa ia berkata; [Umar bin Al Khaththab] pernah menugaskanku sebagai amil zakat. Setelah tugas itu selesai $k u$ laksanakan, dan hasil zakat yang $k u$ kumpulkan telah ku serahkan kepadanya, maka Umar menyuruhku mengambil bagian amil untukku. Lalu jawabku, "Aku bekerja karena Allah, karena itu upahku pun kuserahkan kepada Allah." Umar berkata, "Ambillah apa yang diberikan kepadamu itu, sesungguhnya aku pernah pula bertugas pada masa Rasulullah Shallallahu 'Alaihi Wasallam sebagai amil zakat. Aku menolak pemberian itu seraya menjawab seperti jawabanmu pula. Maka Rasulullah Shallallahu 'Alaihi Wasallam pun bersabda: 'Apabila kamu diberi orang suatu pemberian tanpa kamu minta, makanlah atau sedekahkanlah.'" Dan telah menceritakan kepadaku [Harun bin Sa'id Al Aili] telah menceritakan kepada kami [Ibnu Wahb] telah mengabarkan kepadaku [Amru bin Harits] dari [Bukair bin Al Asyajj] dari [Busyr bin Sa'id] dari [Ibnu Sa'di] bahwa ia berkata; [Umar bin Khaththab] pernah menugaskanku sebagai amil zakat. Yakni sebagaimana Hadis Laits. (H.R. Muslim dari seorang Tabi'in yang bernama Ibnu Al-Sa' di)

4. Hadis riwayat Imam Ahmad

$$
\begin{aligned}
& \text { عن انس قال: اتى رجل من بنى تميم الى رسول الله صلى } \\
& \text { الله عليه وسلم فقال: حسبي يارسول الله اذا اديت الزكاة } \\
& \text { الي رسولك فقد برئت منها الي الله ورسولك؟ فقال }
\end{aligned}
$$




$$
\begin{aligned}
& \text { رسول الله صلي الله عليه وسلم 6،نعم " اذا اديتها الي } \\
& \text { رسولي فقد برئت منها فلك اجرها واثمها علي من بدلها } \\
& \text { (رواه احمد) }
\end{aligned}
$$

Riwayat dari Anas. Ra ia berkata: Datang seseorang dari Bani Tamim kepada Rasululllah Saw, seraya berkata: Apakah cukup bagiku ya Rasulullah jika aku tunaikan zakat kepada utusanmu sehingga aku sudah terbebas dari kewajiban zakat Allah dan Rasulullah?. Rasulullah Saw bersabda: Ya, apabila kamu tunaikan zakat kamu kepada utusanku maka kamu sudah terbebas dari kewajiban zakat tersebut, kamu berhak mendapatkan pahalanya, dan dosanya akan kembali kepada orang-orang yang menukar zakat tersebut. (H.R. Imam Ahmad)

\section{Fatwa MUI tentang Amil}

Fatwa MUI Nomor 8 Tahun 2011 tentang Amil Zakat, yaitu: (MUI, Fatwa MUI Nomor 8 Tahun 2011 tentang Amil Zakat, http://mui.or.id diakses pada 14 Desember 2015)

1. Amil zakat adalah:

a. Seseorang atau sekelompok orang yang diangkat oleh Pemerintah untuk mengelola pelaksanaan ibadah zakat; atau

b. Seseorang atau sekelompok orang yang dibentuk oleh masyarakat dan disahkan oleh Pemerintah untuk mengelola pelaksanaan ibadah zakat.

2. Amil zakat harus memenuhi syarat sebagai berikut :

a. Beragama Islam;

b. Mukallaf (berakal dan baligh);

c. Amanah;

d. Memiliki ilmu pengetahuan tentang hukum-hukum zakat dan hal lain yang terkait dengan tugas amil zakat.
3. Amil zakat memiliki tugas:

a. Penarikan/pengumpulan zakat yang meliputi pendataan wajib zakat, penentuan objek wajib zakat, besaran nisab zakat, besaran tarif zakat, dan syarat-syarat tertentu pada masingmasing objek wajib zakat;

b. Pemeliharaan zakat yang meliputi inventarisasi harta, pemeliharaan, serta pengamanan harta zakat; dan

c. Pendistribusian zakat yang meliputi penyaluran harta zakat agar sampai kepada mustahik zakat secara baik dan benar, dan termasuk pelaporan.

4. Pada dasarnya, biaya operasional pengelolaan zakat disediakan oleh Pemerintah (ulil amr).

5. Dalam hal biaya operasional tidak dibiayai oleh Pemerintah, atau disediakan Pemerintah tetapi tidak mencukupi, maka biaya operasional pengelolaan zakat yang menjadi tugas amil diambil dari dana zakat yang merupakan bagian amil atau dari bagian $F i$ Sabilillah dalam batas kewajaran, atau diambil dari dana di luar zakat.

6. Kegiatan untuk membangun kesadaran berzakat - seperti iklan - dapat dibiayai dari dana zakat yang menjadi bagian amil atau $F i$ Sabilillah dalam batas kewajaran, proporsional dan sesuai dengan kaidah syariat Islam.

7. Amil zakat yang telah memperoleh gaji dari negara atau lembaga swasta dalam tugasnya sebagai amil tidak berhak menerima bagian dari dana zakat yang menjadi bagian amil. Sementara amil zakat yang tidak memperoleh gaji dari negara atau lembaga swasta berhak menerima bagian dari dana zakat yang menjadi bagian amil sebagai imbalan atas dasar prinsip kewajaran.

8. Amil tidak boleh menerima hadiah dari muzaki dalam kaitan tugasnya sebagai amil. 
9. Amil tidak boleh memberi hadiah kepada muzaki yang berasal dari harta zakat.

\section{Karakteristik Amil}

Amil yang seperti apa yang diharapkan bisa membawa misi suci pembangunan zakat ini? Paling tidak ada empat karakteristik yang harus dimiliki amil. (Irfan Syauqi Beikh, Koran Media Indonesia, 24 September 2012)

1. Keberadaan amil harus memiliki payung hukum. Sebagaimana makna tersirat dari pengertian amil dalam fatwa MUI nomor 8 Tahun 2011 tentang Amil Zakat, amil harus memiliki legalitas dan kewenangan yang dijamin oleh undang-undang atau hukum positif. Keberadaan UU No 23 tahun 2011 ini merupakan dasar hukum bagi terbentuknya institusi amil yang memiliki posisi yuridis yang kuat. Pemerintah Indonesia telah membentuk Badan Amil Zakat Nasional atau disingkat BAZNAS. Di samping BAZNAS juga terdapat LAZ untuk membantu pengelolaan zakat.

2. Amil harus amanah dalam melaksanakan tugasnya. Institusi amil harus transparan, akuntabel, dan dapat mempertanggungjawabkan kegiatannya secara terbuka kepada publik. Program-programnya harus jelas dan terarah, baik dari sisi penghimpunan, pendistribusian, maupun pendayagunaan. Demikian pula halnya dengan aspek pelaporan dan pertanggungjawaban.

3. Amil harus bekerja secara profesional. Amil harus bekerja full time mengurus zakat dalam artian tidak bekerja sampingan dalam mengurus zakat. Orang-orang yang bekerja pada lembaga pengelola zakat, haruslah mereka yang memiliki dedikasi dan komitmen untuk bekerja secara penuh waktu dan profesional dalam mengelola dana zakat. Tidak bisa seorang amil bekerja secara asal-asalan, apalagi muncul hanya setahun sekali pada saat Ramadhan. Karena itu, menurut ekonom Monzer Kahf, sebagai kepala negara, Rasulullah Saw. telah menugaskan 25 orang sahabat sebagai petugas amil yang bekerja dengan penuh dedikasi.

4. Amil bekerja dalam sebuah sistem yang terintegrasi dan terkoordinasi dengan baik. Dalam hal ini UU No 23/2011 tentang Pengelolaan Zakat memberikan ruang bagi proses integrasi ini, di mana seluruh institusi zakat formal, baik LAZ maupun BAZNAS daerah, berada di bawah koordinasi BAZNAS Pusat. Integrasi dan sinergi ini sangat dibutuhkan mengingat tantangan yang dihadapi ke depannya semakin kompleks.

\section{Pendapat Ulama tentang Berzakat Melalui Amil}

Pendapat Ulama Mazhab tentang zakat yang melalui badan amil zakat:

1. Menurut Mazhab Syafi'i

Menurut Mazhab ini yang dijadikan pilihan dalam mazhab Syafi'i, zakat boleh disalurkan melalui amil zakat yang dibentuk pemerintah (imam), apalagi jika pemerintahan tersebut adil kepada rakyatnya.

2. Menurut Mazhab Hambali

Menurut Mazhab ini yang paling baik menyalurkan zakat dilakukan sendiri oleh muzaki, namun jika tetap ingin melalui badan amil zakat tetap boleh dan sah. (Ahmad Rofiq, 2004: t.h.)

3. Menurut Hanabillah,

Menurut Mazhab ini disunatkan para muzaki menyerahkan zakatnya sendiri, dengan demikian yakin betul ia, bahwa zakatnya sampai kepada mustahiknya, 
tetapi sekiranya yang menyerahkannya kepada pemerintah, diperbolehkan juga ( jaiz).

4. Menurut Malikiyah

Menurut Mazhab ini ada mempunyai ketentuan lain, yaitu apabila imam itu adil (ingat, amil adalah aparat dari pada imam sama dengan pemerintah), diserahkan kepada imam dan sekiranya tidak adil, dapat diserahkan sendiri kepada mustahiknya (Fattah Santoso dkk, 2004: 124).

\section{URGENSI BERZAKAT MELALUI AMIL DALAM PANDANGAN ILMU EKONOMI ISLAM}

Paling tidak ada enam urgensi berzakat melalui amil dalam pandangan ilmu ekonomi Islam, yaitu:

1. Sesuai dengan petunjuk Alquran dan Sunnah.

Berzakat melalui amil sesuai dengan Alquran dan Sunnah sebagaimana telah disebutkan sebelumnya pada pembahasan dasar hukum amil dalam Alquran dan Sunnah. Menyalurkan zakat kepada amil bagian dari penerapan ekonomi Islam.

Demi kemaslahatan umat maka mengikuti praktek berzakat zaman Nabi dan sahabat merupakan suatu keharusan. Selama ini, yang berkembang di tengah masyarakat adalah pemahaman bahwa ibadah zakat itu lebih afdhal dan lebih baik apabila muzaki, atau wajib zakat, menyalurkan langsung zakatnya kepada para mustahik, tanpa melalui perantara amil.

Jika merujuk kepada apa yang telah dipraktekkan oleh Rasulullah Saw, maka kita akan menemukan fakta sebaliknya. Yaitu, tidak pernah ada contohnya di zaman Nabi, seorang muzaki menyalurkan zakatnya secara langsung kepada mustahik tanpa melalui amil, kecuali infak dan sedekah yang memang bebas untuk disalurkan secara langsung. Praktek ini kemudian berlanjut di masa khualafur rasyidin (Badan Amil Zakat Nasional Kota Pematang siantar, Urgensi Zakat Via Amil, https: //id-id.facebook.com/ permalink. php diakses pada29Nopember 2015).

Membayar zakat ke amil zakat jauh lebih utama daripada membayar langsung ke mustahik, meskipun itu sah-sah saja. Selain keutamaan-keutamaan di atas, zakat memang harus dibayarkan lewat amil zakat. Sebab, hal itu biasa dilakukan dan dicontohkan oleh Rasulullah Saw dan para sahabat sesudahnya. Di samping itu, dalam QS At-Taubah: 60 Allah Swt juga memasukkan amil atau petugas zakat sebagai salah satu mustahik zakat. Ini berarti, memang zakat itu harus ada yang mengurusnya (Majalah Zakat Edisi Mei 2013, http:// pusat.baznas.go.id/, diakses pada 01 Juni 2016).

2. Untuk mengoptimalkan tingkat kedisiplinan pembayar zakat.

Dengan berzakat melalui amil maka muzaki terbiasa untuk teratur dalam membayarkan zakat. Kedisiplinan membayar zakat akan bisa ditingkatkan dengan keistiqamahan membayar zakat melalui amil. Amil bisa mengingatkan muzaki jika terlupa membayar zakat.

Salah satu prinsip ilmu ekonomi Islam bahwa seorang Muslim yang kekayaannya melebihi ukuran tertentu (nisab) diwajibkan membayar zakat. Zakat merupakan alat distribusi sebagian kekayaan orang kaya, yang ditujukan untuk orang miskin dan mereka yang membutuhkan. Dalam diri manusia terdapat 
sifat lupa, maka untuk meminimalisir sifat lupa membayar zakat bantuan amil sangat diharapkan.

Pengelolaan zakat oleh lembaga pengelola zakat, apalagi yang memiliki kekuatan hukum formal, akan memiliki beberapa keuntungan, salah satunya untuk menjamin kepastian dan disiplin pembayar zakat (Hafidhuddin, 2006: 79).

3. Untuk menjaga perasaan rendah diri para mustahik terhadap muzaki.

Jika muzaki menyerahkan langsung dana zakatnya, mustahik seringkali merasa rendah diri. Sehingga, lembaga pengelola zakat (BAZNAS atau LAZ) diharapkan menjadi perantara antara mustahik dan muzaki. Mustahik atau penerima bantuan, juga merupakan salah satu rantai dalam kehidupan sosial. Meski peran mustahik adalah sebagai yang membutuhkan, namun bukan berarti pihak yang pantas untuk direndahkan. Lembaga pengelola zakat bisa menjadi mediator antara muzaki dengan mustahik, yang salah satunya untuk menjaga perasaan dan harkat mustahik.

Praktek membagi-bagikan uang kepada ribuan mustahik yang mengantri, cenderung tidak menimbulkan kemaslahatan. Terkadang ada korban berjatuhan bahkan sampai meninggal dunia demi mendapatkan uang puluhan ribu rupiah. Dari sisi kemanusiaan, praktik tersebut kurang manusiawi dan cenderung merendahkan harkat dan martabat mustahik.

Dalam ilmu ekonomi Islam dituntut kegiatan ekonomi dalam kerangka kemaslahatan agar manusia bisa memperoleh falah. Praktik pendistribusian zakat yang terorganisir oleh amil adalah salah satu wujud penerapan kemaslahatan dalam berzakat. Pendistribusian zakat yang secara langsung cenderung tidak terorganisir sehingga bisa menelan korban jiwa dalam proses pendistribusiannya.

Ada banyak pelajaran yang dapat diambil dari tragedi meninggalnya penerima zakat akibat berdesakan menerima zakat yang disalurkan langsung oleh muzaki.

a. Sudah saatnya kembali menyalurkan zakat melalui amil yang amanah.

b. Sudah saatnya lembaga-lembaga amil zakat yang ada di Indonesia bersatu dan memperkuat kerja sama dan meningkatkan profesionalisme, sehingga kepercayaan masyarakat meningkat. Kepercayaan tidak bisa dipaksakan, melainkan harus melalui sebuah proses pembuktian nyata.

c. MUI hendaknya mengeluarkan fatwa tentang berzakat melalui lembaga amil zakat.

d. Perlunya penguatan aspek konsistensi pemerintah pusat maupun daerah terkait regulasi zakat utamanya dalam penerapan UU No. 23 Tahun 2011 tentang pengelolaan zakat dan peraturan terkait lainnya.

4. Untuk mencapai efisiensi dan efektivitas serta sasaran dalam pendayagunaan zakat.

Dalam Undang-undang pasal 3 digariskan, pengelolaan zakat bertujuan:

a. Meningkatkan efektivitas dan efisiensi pelayanan dalam pengelolaan zakat.

b. Meningkatkan manfaat zakat untuk mewujudkan kesejahteraan masyarakat dan penanggulangan kemiskinan.

Untuk menyahuti tujuan ini berbagai program pendayagunaan zakat telah diluncurkan lembaga pengelola zakat, salah satunya yang menyita perhatian adalah program zakat produktif. 
Dengan demikian pendistribusian zakat tidak berorientasi jangka pendek tetapi berorientasi jangka panjang, sehingga mustahik berubah menjadi muzaki sebagai cerminan kesejahteraan.

Dalam ekonomi Islam, berbagai jenis sumber daya dipandang sebagai pemberian atau titipan Allah kepada manusia. Manusia harus memanfaatkannya seefisien dan seoptimal mungkin dalam aktifitasnya guna memenuhi kesejahteraan bersama di dunia, yaitu untuk diri sendiri dan untuk orang lain. Dengan pendayagunaan zakat secara optimal berarti kaum muslimin berusaha memanfaatkan titipan Allah Swt secara efisien dan produktif. Setidaknya kita bisa menilik ke belakang tentang upaya yang dilakukan oleh Khalifah Umar ibn Khattab.

Umar mengatakan memberi hendaklah mencukupi, memberi orang miskin zakat tidak sekedar menutup kelaparan mereka dengan beberapa suap makanan atau melepaskan kesusahan mereka dengan beberapa dirham. Seorang laki-laki datang mengadukan kesusahan kepada Umar, kemudian Umar memberi 3 ekor unta. Pemberian itu bukan hanya sekedar untuk menghilangkan kesusahan, sebab unta adalah harta yang paling berguna bagi mereka pada masa itu. Umar berkata kepada para pegawainya yang bekerja membagikan zakat "berikanlah sedekah itu kepada mereka walaupun salah seorang dari mereka baru dapat tercukupi dengan seratus ekor unta. Atha berkata apabila seseorang memberikan zakat harta kepada keluarga kaum muslimin sampai mereka menjadi kaya, maka hal itu lebih aku senangi". (Abu Ubaid al-Qasim, 1986: 560-561)
Dengan berzakat melalui amil maka dana zakat yang disalurkan kepada mustahik dapat lebih berdaya guna. Dengan berzakat melalui amil, amil akan memperoleh dana zakat yang banyak. Dengan begitu, apabila amil ingin membuat program menyejahterakan suatu desa yang mayoritasnya masyarakat miskin, programprogram zakat tersebut dengan mudah dilaksanakan.

Nominal bantuan zakat yang dapat diberikan pun akan secara otomatis lebih besar dibandingkan dengan muzaki langsung mendistribusikan zakatnya kepada mustahik yang banyak. Misalnya pada awalnya muzaki akan berzakat dengan nominal Rp 50.000,per orang. Tetapi, kemudian dikurangi menjadi Rp 25.000,- setelah melihat fakta jumlah yang datang lebih banyak dari yang direncanakan.

Kondisi tersebut menimbulkan sejumlah pertanyaan, apabila ternyata yang datang jauh lebih besar dari itu, maka akan dikurangi menjadi berapa lagi? Dan apa yang bisa diperbuat oleh penerima zakat dengan uang yang hanya Rp. 25.000,- atau kurang dari itu? Apakah mereka semua termasuk dalam ashnaf? Ini merupakan pertanyaan sebagai dasar evaluasi zakat tanpa melalui amil.

Padahal jika melalui amil, maka program penyaluran zakat menjadi lebih efektif karena amil akan mendapat dana yang cukup dari muzaki. Jika muzaki membayar zakat melalui amil zakat maka dana zakat yang dihimpun dapat lebih besar.

Dengan dana yang besar program untuk menyejahterakan mustahik dengan skema zakat produktif dapat direalisasikan. Di Indonesia terdapat 
pengelola zakat seperti BAZNAS dan LAZ. Sebagai contoh dapat dilihat dari program yang dilakukan oleh BAZNAS
Kabupaten Tanah Datar. Melalui program zakat produktif yang dinamai Tanah Datar Makmur.

Tabel 1. Pengumpulan dan Pendistribusian Zakat Produktif

BAZNAS Kabupaten Tanah Datar Tahun 2013 s.d. 2015

\begin{tabular}{|r|r|r|r|}
\hline No. & Tahun & $\begin{array}{r}\text { Total Pengumpulan } \\
\text { Zakat (Rp.) }\end{array}$ & $\begin{array}{l}\text { Total Pendistribusian } \\
\text { Zakat Produktif (Rp.) }\end{array}$ \\
\hline 1 & 2013 & $8.418 .272 .757,-$ & $2.795 .398 .000,-$ \\
\hline 2 & 2014 & $8.754 .155 .665,-$ & $2.522 .051 .000,-$ \\
\hline 3 & 2015 & $9.179 .036 .735,-$ & $1.254 .584 .000,-$ \\
\hline
\end{tabular}

Sumber: Dokumen BAZNAS Tanah Datar

Dari data yang disajikan pada tabel 1 diperoleh keterangan bahwa pada tahun 2013 pendistribusian zakat produktif sebesar Rp. 2.795.398.000,adalah 33,21 \% dari total pengumpulan. Pada tahun 2014 pendistribusian zakat produktif sebesar Rp. 2.522.051.000,adalah $28,81 \%$ dari total pengumpulan. Sedangkan pada tahun 2015 pendistribusian zakat produktif sebesar Rp. 1.254.584.000,- adalah 13,67 \% dari total pengumpulan. Dengan dana yang besar tersebut maka BAZNAS Tanah Datar dapat membantu mustahik dengan nominal yang agak besar rentang Rp. 500.000,- s.d. Rp. 2.000.000,sehingga bisa menyejahterakan.

5. Untuk memperlihatkan syiar Islam dalam hal pengelolaan potensi ekonomi umat.

Islam adalah agama yang sangat memperhatikan masalah sosial kemasyarakatan, dengan zakat yang dilakukan secara berjamaah melalui amil merupakan pelaksanaan syiar Islam. Dengan zakat melalui amil kita berharap masalah-masalah perekonomian dan kesenjangan sosial di tengah masyarakat dapat teratasi.

Adapun rahasia di balik ditugaskannya para amil antara lain agar terciptanya jaminan bagi si fakir akan haknya, untuk memelihara kehormatan mereka, lebih memungkinkan distribusi zakat yang lebih tepat dan tidak terkonsentrasi pada sebagian orang saja. Di samping itu, ada beberapa sasaran zakat yang berhubungan dengan kemaslahatan bersama kaum Muslimin seperti dalam mengorganisasikan jihad $f i$ sabilillah dan mempersiapkan para da'i untuk menyampaikan risalah Islam, sehingga baik pengumpulannya maupun pendistribusiannya tidak bisa dilakukan secara perorangan (Al-Qaradhawi dalam Baga, 1997: 23).

Sistem ekonomi Islam sangat menekankan adanya suatu distribusi kekayaan dan pendapatan yang merata sebagaimana yang tercantum dalam firman Allah Swt.,

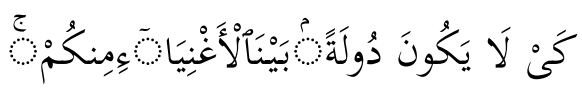

"...supaya harta itu tidak hanya beredar di antara orang-orang kaya dari kalangan kamu..." (Q.S. al-Hasyr [59]: 7)

Dengan berzakat melalui amil kecenderungan konsentrasi kekayaan pada sekelompok elite masyarakat dapat dihindari atau diminimalisir, sehingga dapat bermuara pada zakat 
yang mensejahterakan sekaligus mensyiarkan Islam yang rahmatan lil 'alamin.

6. Untuk menghasilkan data muzaki dan mustahik yang akurat.

Data akurat diperlukan untuk menghindari kemungkinan terjadinya tumpang tindih (overlapping) dan kesalahan distribusi zakat kepada yang tidak berhak sehingga lebih menjamin terciptanya pemerataan atau keadilan sebagaimana yang diserukan dalam ilmu ekonomi Islam.

Jika banyak muzaki yang mendistribusikannya zakatnya secara langsung namun ke mustahik yang sama sementara mustahik lainnya tidak mendapat dana zakat, ini tentu menimbulkan polemik berupa kesenjangan. Dalam ilmu ekonomi Islam diajarkan keadilan, untuk mewujudkan keadilan dalam pendistribusian zakat diperlukan pendataan yang akurat oleh amil, sehingga tidak akan terjadi overlapping. Dengan profesionalitas amil maka pendistribusian zakat oleh amil dapat lebih merata dan mensukseskan misi zakat sebagai penggerak ekonomi umat.

Amil yang bergerak berdasarkan SOP dapat menyeleksi calon mustahik sehingga menghindari pendistribusian zakat kepada yang tidak berhak.

Karena salah satu pekerjaan utama amil mendistribusikan zakat, maka dengan ketersediaan waktu dan dengan dukungan infrastruktur yang memadai, amil akan dapat menyeleksi calon mustahik dengan tepat dan lebih baik. Ini penting karena muzaki yang ingin menyalurkan langsung pada mustahik pada umumnya tidak mempunyai informasi yang cukup mengenai calon mustahik sehingga sangat mungkin terjadi orang yang akhirnya memperoleh zakat tersebut ternyata tidak termasuk dalam ashnaf zakat seperti yang telah diperintahkan dalam Alquran. Untuk konteks Indonesia ini penting mengingat tidak sedikit orang yang pekerjaannya hanya mengirimkan proposal dana pada calon donator, padahal orang tersebut tidaklah miskin.

Amil dituntut mempunyai database yang lengkap dan akurat. Database tersebut meliputi informasi tentang muzaki dan juga mustahik. Sehingga pihak-pihak yang terkait mudah mengambil keputusan dengan data yang ada.

Adanya database ini sangat penting mengingat dengan inilah perjalanan mustahik menuju tingkat yang lebih baik yaitu muzaki dapat ditelusuri dengan baik. Ini juga dapat menstimulasi amil untuk membuat program ekonomi pemberdayaan mustahik sehingga statusnya diharapkan berubah menjadi muzaki.

\section{PENUTUP}

\section{Kesimpulan}

Dasar hukum berzakat melalui amil pun terdapat dalam Alquran seperti Q.S. at-Taubah [9]: 60 dan 130 dan beberapa Hadis Nabi. Untuk memperkuat institusi Amil, MUI juga telah mengeluarkan fatwa Nomor 8 Tahun 2011 tentang Amil Zakat. Berzakat melalui amil juga didukung berdasarkan pendapat ulama mazhab.

Selama ini, yang berkembang di tengah masyarakat adalah pemahaman bahwa ibadah zakat itu lebih afdhal dan lebih baik apabila muzaki, atau wajib 
zakat, menyalurkan langsung zakatnya kepada para mustahik, tanpa melalui perantara amil. Padahal berzakat melalui amil bukanlah sesuatu yang baru karena telah dipraktekkan di zaman Rasulullah dan Khalifah al-Rasyidin.

\section{Saran}

Para muzaki agar lebih memahami urgensi berzakat melalui amil. Para pengelola zakat atau amil untuk terus bekerja secara profesional mengharap ridha Allah.

\section{DAFTAR KEPUSTAKAAN}

al-Utsaimin, Muhammad bin shalih. 2011. Fiqih Zakat Kontemporer, Surakarta: Al-Qowam.

Al-Zuhayly, Wahbah. 1995. Zakat Kajian Berbagai Mazhab, diterjemahkan oleh Agus Efendi dan Bahruddin Fannany, Bandung: PT Remaja Rosdakarya.

Ambary, Hasan Muarif, dkk. 1999. Ensiklopedi Islam, Jakarta: PT Ichtiar Baru Van Hueve, jilid 5.

Asnaini, 2008. Zakat Dalam Prespektif Hukum Islam, Yogyakarta: Pustaka Pelajar.

Badan Amil Zakat Nasional Kota Pematang siantar, Urgensi Zakat Via Amil, https://id-id.facebook.com/ permalink.php diakses pada 29 Nopember 2015

Baga, Lukman Mohammad, 1997. Sari Penting Kitab Figh Zakat Yusuf Al-Qardhawy, Bogor, tp.

Basyir, Ahmad Azhar. 1997. Hukum Zakat, Yogyakarta: Majelis Pustaka Pimpinan Pusat Muhammadiyah.
Beikh, Irfan Syauqi, Koran Media Indonesia, 24 September 2012

Dokumen BAZNAS Tanah Datar.

Hafidhuddin, Didin. 2002. Zakat dalam Perekonomian Modern. Jakarta: Gema Insani.

Perzakatan di Indonesia," dalam Kuntarno Noor Aflah (ed), Zakat $\mathcal{E}$ Peran Negara, Jakarta: Forum Zakat.

Kurnia, Hikmat dan Hidayat, A.. 2008. Panduan Pintar Zakat Harta Berkah, Pahala Bertambah Plus Cara Tepat \& Mudah Menghitung Zakat. Jakarta: Qultum Media.

Majalah Zakat Edisi Mei 2013, http://pusat.baznas.go.id/, diakses pada 01 Juni 2016)

Qardhawi, Yusuf. 2002. Figh Zakat, edisi Indonesia Hukum Zakat, diterjemahkan oleh Salman Harun, Didin Hafidhuddin dan Hasanuddin, Jakarta: PT. Pustaka Litera Antar Nusa dan Badan Amil Zakat dan Infak/ Shodaqoh DKI Jakarta.

Rofiq, Ahmad, 2004. Figh kontekstual. Dari normatif ke pemaknaan sosial, semarang, Pustaka pelajar.

Salam, Abi Ubaid al-Qasim. 1982. Alamwal, Dar al-Khatab al-Ilmiyah, Beirut.

Santoso, Fattah dkk, 2004. Studi Islam 3, Surakarta: Lembaga Studi Islam.

Shiddiqi, Nouruzzaman t.th. Figh Indonesia : Penggagas dan Gagasannya, Yogyakarta: Pusat Pelajar.

Shihab, M. Quraish. 2002 Tafsir AlMishbah: Pesan, Kesan, dan Keserasian Al-Qur'an, Jakarta: Lentera Hati. 
100

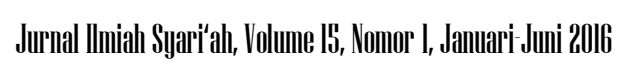

Shoim, Abdul Bari. 1978. Zakat Kita, Kendal: Pimpinan DaerahMuhammadiyah Kendal.

Zuhdi, Masjfuk. 1997. Masail Fiqhiyah:

Kapita Selekta Hukum Islam, Jakarta:
PT. Toko Gunung Agung, Cet. Ke10, 1997 